\section{Apocrine hidrocytoma in an Awassi sheep}

\author{
Wael M. Hananeh,1 Mousa Daradka,2 \\ Zuhair Bani Ismail,2 \\ Huthaifa S. Ababneh ${ }^{3}$ \\ Departments of 1Pathology and Public \\ Health, ${ }^{2}$ Veterinary Clinical Sciences, \\ Faculty of Veterinary Medicine, Jordan \\ University of Science and Technology, \\ Irbid; ${ }^{3}$ National Center for Agricultural \\ Research and Extension, Baq'a, Jordan
}

\begin{abstract}
Hidrocytomas are benign cystic lesions of sweat apocrine glands. It is a recognized condition in cats and dogs, but has never been reported in sheep. In this case, a 5-year-old Awassi ewe was presented for ocular evaluation. The left eye had a 1.0-cm-diameter dome shaped mass containing clear fluids and was protruded from the palpebral eyelid margin near the lateral canthus. The cyst was surgically removed and revealed apocrine hidrocytoma via histopathology. Seven months post-surgery, neither cyst recurrence nor additional masses were present. To the best of our knowledge, this is the first case of apocrine hidrocytoma in sheep.
\end{abstract}

\section{Case Report}

A 5-year-old Awassi ewe, was presented to the Veterinary Health Center at Jordan University of Science and Technology for evaluation of a peri-ocular mass. The left eye had an approximately $1.0-\mathrm{cm}$ in diameter solitary dome shaped ocular cyst (Figure 1). The cyst had a smooth surface, soft and was filled with transparent clear fluid. It exhibited a soft pinkish thin translucent wall and it had multiple areas of brownish pigmentation. The cyst was mobile, not well delineated and protruded from the palpebral eyelid margin near the lateral canthus of the left eye. The vision and anatomy of the eye were not affected by the presence of the cyst. However, the movement of the eyelids was hampered. Excessive lacrimation of the affected eye was evident. The owner did not know when the cyst has emerged. No masses were present elsewhere. Treatment in this case was achieved by complete surgical removal of the mass. Follow up seven months post ocular surgery revealed neither complications nor cyst recurrence (Figure 2).

Immediately after surgical removal, the mass was fixed in formalin for $24 \mathrm{~h}$, and processed routinely for histopathological evaluation. Five micrometer tissue sections were made and slides were stained with Hematoxylin and Eosin stain and examined using light microscopy. The mass was composed of multilocular cystic structures of various sizes. The structures were lined by cuboidal to columnar cells and vacuolated secretory cells (Figure 3 ). They were surrounded by moderate edema and collagenous connective tissue. Few scattered lymphocytes, plasma cells and macrophages were seen infiltrated the cyst connective tissue wall. Based on the gross and histological findings, a diagnosis of apocrine hidrocytoma was made.

\section{Discussion and Conclusions}

Hidrocytomas are benign cystic lesions of sweat apocrine glands. ${ }^{1-4}$ Similar lesions were reported in cats and dogs. ${ }^{5}$ In a retrospective study of feline cases of tumors involving the eyelids or nictitans, apocrine hidrocystomas accounted for $7 \%$ of the eyelid tumors out of 43 diagnosed tumors. ${ }^{6}$ In that study, only one case, the tumor reoccurred after surgical treatment. In this case report neither surgical complication nor tumor recurrence was present 7 months post-surgery.

Clinically, the tumor appeared translucent with areas of brownish pigmentation; however, in the feline case the cysts were darkly pigmented. ${ }^{5}$ Furthermore, apocrine hidrocytomas in cats were reported to exhibit multiple lesions,${ }^{5,6}$ while in this case, the lesion was solitary.

In man, hidrocytomas could be either eccrine or apocrine types.1,2,7,8 Apocrine type usually occurs as a solitary nodule and commonly involves the eyelid margin. ${ }^{7}$ The same authors stated that histologically examined

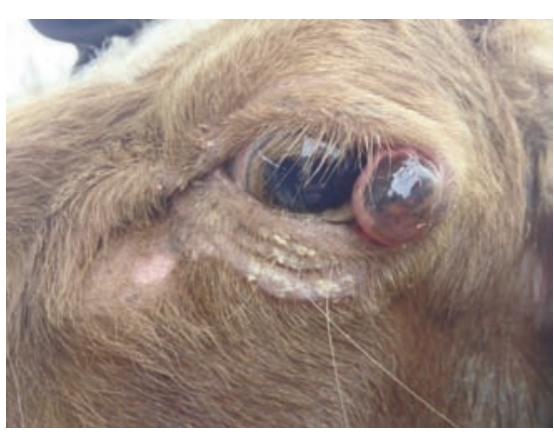

Figure 1. A $1.0-\mathrm{cm}$ in diameter, domeshaped, darkly pigmented, solitary ocular cystic lesion was present attached to the palpebral membrane of the lower left eye lid in a 5-year-old Awassi sheep.
Correspondence: Wael M. Hananeh, Department of Pathology and Public Health, Faculty of Veterinary Medicine, Jordan University of Science and Technology, Ar Ramtha, Irbid 22110, Jordan.

Tel.: +962.272 .01000$, Ext 22060

Fax: +962.270 .95117 .

E-mail: whananeh@just.edu.jo

Key words: Awassi sheep, eyelid, ocular cyst.

Contributions: the authors contributed equally.

Received for publication: 15 April 2014.

Accepted for publication: 7 May 2014.

This work is licensed under a Creative Commons Attribution NonCommercial 3.0 License (CC BYNC 3.0).

○C Copyright W.M. Hananeh et al., 2014 Licensee PAGEPress srl, Italy

Veterinary Science Development 2014; 4:5439 doi:10.4081/vsd.2014.5439

eccrine hidrocytomas are usually seen as unilocular cysts while apocrine counterparts appear as multilocular cyst. ${ }^{7}$ Furthermore, it

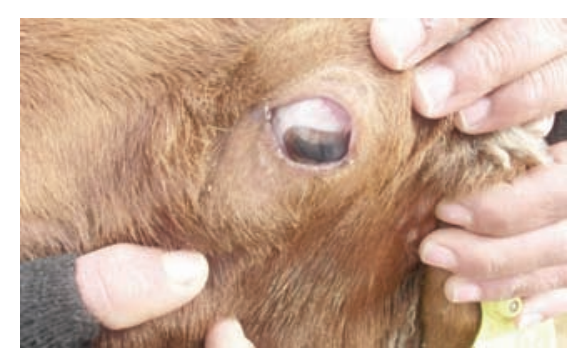

Figure 2. Neither cyst recurrence nor complication was present seven months post surgery.

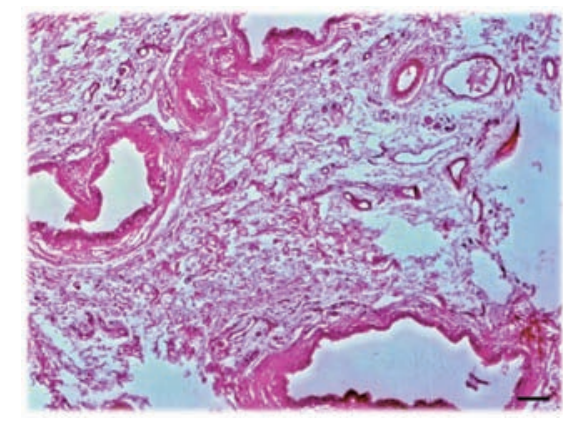

Figure 3. The lesion consisted of multiple cystic structures of various sizes that are lined by single or multiple layers of cuboidal to attenuated columnar cells and vacuolated secretory cells. (Hematoxylin and Eosin, bar: $50 \mu \mathrm{m}$.) 
has been reported that apocrine hidrocytoma has secretory cells while eccrine hidrocytoma has not. ${ }^{8}$ All of these data were in support of our diagnosis of apocrine hidrocytoma in this sheep.

Finally, other cystic structures involving the eyelids in domestic animals have been reported. ${ }^{9-11}$ Cystic dilatation of the nasolacrimal system is usually associated with the obstruction of the duct distal to the cystic cavity. ${ }^{9}$ Chalazia, which has a yellowish color containing lipid secretions of the tarsal gland, also has been reported in animals. 11 In this case reported her, neither dilatation of the nasolacrimal duct was present distal to the affected area nor lipid contents in the cyst were seen.

To the best of our knowledge, this case was the first case to be reported in literature of hidrocytoma in sheep.

\section{References}

1. Klein W, Chan E, Seykora JT. Tumors of the epidermal appendages. In: Elder DE, ed. Lever's histopathology of the skin. 9th ed. Philadelphia: Lippincott Williams \& Wilkins; 2005. pp 892-893.

2. Anzai S, Goto M, Fujiwara S, Da T. Apocrine hidrocystoma: a case report and analysis of 167 Japanese cases. Int J Dermatol 2005;44:702-3.

3. Obaidat NA, Ghzarian DM. Bilateral multiple axillary apocrine hidrocystomas associated with benign apocrine hyperplasia. $\mathrm{J}$ Clin Pathol 2006;59:779.

4. Sehgal S, Agarwal R, Singh S, Goyal P. Fine-needle aspiration cytology of eccrine hidrocystoma. CytoJournal 2012;9:6.

5. Chaitman J, Van der Woerdt A, Bartick TE. Multiple eyelid cysts resembling apocrine hidrocystomas in three Persian cats and one Himalayan cat. Vet Pathol 1999;36: 474-6.

6. Newkirk KM, Rohrbach BW. A retrospective study of eyelid tumors from 43 cats. Vet Pathol 2009;46:916-27.

7. Sarabi K, Khachemoune A. Histiocytomas. A brief review. Medscape Gen Med 2006;8:57.

8. Alfadley A, Al Aboud K, Tulba A, Mazen M. Multiple eccrine hidrocystomas of the face. Int J Dermatol 2001;40:125-9.

9. Lussier B, Carrier M. Surgical treatment of recurrent dacryocystitis secondary to cystic dilatation of the nasolacrimal duct in a dog. J Am Anim Hosp Assoc 2004;40:216-9.

10. Van der Woerdt A, Wilkie DA, Gilger BC, et al. Surgical treatment of dacryocystitis caused by cystic dilatation of the nasolacrimal system in three dogs. J Am Vet Med Assoc 1997;211:445-7.

11. Grahn BH, Sandmeyer LS. Diagnostic ophthalmology. Can Vet J 2010;51:327. 